\title{
Going with the affective flows of digital school absence text messages
}

\author{
Linnea Bodén \\ Journal Article
}

\section{Tweet}

N.B.: When citing this work, cite the original article.

Original Publication:

Linnea Bodén , Going with the affective flows of digital school absence text messages, Learning, Media and Technology, 2016, pp.1-14.

http://dx.doi.org/10.1080/17439884.2017.1247859

Copyright: Routledge/Taylor \& Francis

Postprint available at: Linköping University Electronic Press

http://urn.kb.se/resolve?urn=urn:nbn:se:liu:diva-132603

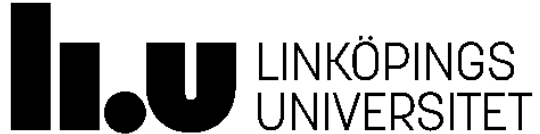




\title{
Going with the Affective Flows of Digital School Absence Text Messages
}

\author{
Linnea Bodén
}

Department of Social and Welfare Studies, Linköping University, Norrköping, Sweden

Correspondence to Linnea Bodén linnea.boden@buv.su.se Department of Social and Welfare Studies, Linköping University, ISV, SE- 60174 Norrköping, Sweden

Current address: Department of Child and Youth Studies, Stockholm University, SE-106 91

Stockholm, Sweden

\section{Acknowledgements:}

I am grateful for the opportunity to discuss the paper with the seminar group (Re)acting sisters: Lena Aronsson, Teresa Elkin Postila, Christine Eriksson, Karin Gunnarsson, Hillevi Lenz Taguchi and Emilie Moberg. Thanks to Eva Reimers and Ann-Marie Markström for valuable comments and to Constance Ellwood for the proof reading. Thanks also to the two anonymous reviewers. Your comments and suggestion have strengthened the arguments in the paper.

This is an Accepted Manuscript of an article published by Taylor \& Francis in Learning, Media and Technology on 01 November 2016, available online: http://www.tandfonline.com/10.1080/17439884.2017.1247859 


\title{
Going with the Affective Flows of Digital School Absence Text Messages
}

\begin{abstract}
Focusing on digital text messages containing information about students' absences and sent to parents by schools, the paper investigates the way school absenteeism is produced within affective assemblages. The paper unfolds a theoretical and methodological approach of 'going with' the text messages, in entanglements of affective flows. The empirical engagements, produced together with multiple agents in two Swedish schools, show that within the assemblages of human and nonhuman bodies, the text messages can become 'stirrers' that evoke nervousness and anxiety, but also excitement and feelings of control that affect the production and conception of absenteeism. The affective flows of text messages thus travel in all directions, with and against notions of linearity. The conclusion emphasizes how the text messages, as affective materialities, are an inextricable part of the production of school absenteeism in multiple and sometimes unexpected ways.
\end{abstract}

Keywords: digital text messages, school absenteeism, affect, affective flows, assemblages

This paper constitutes an engagement with digital text messages that contain information about students' unexcused absences and late arrivals, sent to parents from the computer software Dexter, used by numerous Swedish schools ${ }^{1}$. By focusing on the text messages as intricately entangled in affective assemblages that involve multiple agents, such as smartphones, the software, parents, teachers, students and other human or nonhuman agents, the aim of the paper is to study how school absenteeism is produced within these entanglements. The paper will unfold a story of 'going with' the text messages, as they flow between different spaces, places and times. In this story, the main protagonists are the text messages themselves. They are transformed from what in one version of the story might be perceived as passive digital materialities sent back and forth between human senders and receivers, to another version where the text messages can be perceived as powerful flowing materialities that are both affectively produced and affectively productive. The story will engage in affective flows and intensities as theorized in research engaged in the turn to affect (see for example Gunnarsson 2015; Juelskjær, Staunæs and Ratner 2013; Kofoed and Ringrose 2010), elaborated on in the upcoming section. I begin this story of the digital text messages sitting at my desk in my shared office.

One day in November my colleague Sarah ${ }^{2}$ interrupts me. She comes rushing to my desk with

\footnotetext{
1 All 290 municipalities in Sweden work, or are about to begin working, with various different digital software packages for the registration of absences and presences. Dexter is one of about fifteen different softwares in use and is used in sixty of the municipalities in Sweden. Similar software are in use around the world, for example in Australia, Brazil, China, Denmark, England, Finland, Norway, and the U.S. (Bodén 2016a).

2 All names in the paper are pseudonyms, including the names of the schools. However, because of its widespread use in Swedish municipalities, the name of the software Dexter is not a pseudonym.
} 
her smartphone in her hand: 'What the heck Linnea, I've received a text message that David was late for class'. The message says that David, her 13-year-old son, arrived late to class, and that Sarah can contact the homeroom teacher if she has any questions. Rather than contacting the homeroom teacher, the message forces Sarah to phone her son, and then her partner, and then her son again. After some time, and a number of phone calls, it turns out that David is okay, but Sarah again interrupts me to tell me how upset she is at the messages and the fact that there doesn't seem to be a way of not getting them. Sarah knows I'm interested in the messages since my research project focuses on school absenteeism and on practices related to the registration of students' school absences and presences through digital technologies. The software I am studying is called Dexter. I have engaged with two schools working with Dexter: Björnäng School (Grade 7-9) and Sandö School (Grade 3-9), both located in a municipality in central Sweden. Rather than being a digital technology for supporting teaching and learning in the educational setting, Dexter is part of an increasing amount of technologies in schools that are mainly managerial or administrative (see Selwyn 2011; Williamson 2016). Dexter has an automated text message service connected to it so that text messages are sent to parents if a student arrives late or is absent from a whole lesson. As soon as a teacher has registered information in Dexter, a message is sent, at half-hour intervals, day and night, and parents cannot avoid receiving the information. However, messages are only sent at the first registration, which means that parents will not receive more than one message a day, irrespective of whether or not the child has been tardy or absent several times that day.

The messages can be viewed as a response to the formulations of the Swedish Education Act (SFS 2010:800, 7 kap. 17§), that states that if a student does not attend mandatory activities, the school principal must ensure that parents are informed of this on the same day. The messages are often digitally automated, sent directly from software like Dexter, into which teachers before, during, or after each lesson digitally register the students' absences and presences. These kinds of software and the messages produced have been described as problem-solving tools to make the management of absences more efficient (Bodén 2013; 2015, see also Bhalla et al. 2013; Gavade et al. 2015; Isomursu et al. 2011; Lodha et al. 2015; More and Nayak 2013). They are also seen as enabling real-time information for parents on children's attendance (Ervasti, Isomursu and Kinnula 2009). In the public debate, the 'fast and frequent parental contact' (Sundén Jelmini 2014) that text messages offer is renowned as one reason for improved attendance rates in schools in Sweden. A tougher attitude toward truants is claimed to decrease absenteeism, and a stricter and more rigid control apparatus has been promoted (see for example 
Helmersson 2014; Sundén Jelmini 2014). Furthermore, good and close collaboration between home and school has been highlighted in both public debate and in policy documents in Sweden as crucial to children's development, well-being and lifelong learning (Markström 2013). In contrast, parents' disengagement in their children's learning and schoolwork has been viewed as explanations for different kinds of non-attendance behaviours (Reid 2015, 4-5; see also Attwood and Croll 2006; Carroll 2015). Relations between schools and families have thus been described as a key aspect of school absenteeism (Carroll 1986; Skolverket 2008, 2010). Accordingly, providing parents with information about students' absences and presences are not a new feature (see for example Sandin 1986; Sjöberg 1996). However, the fast and frequent contacts the text messages offer have been understood as a resource to refine the relations between homes and schools. Furthermore, the digital registration and the messages are expected to streamline and improve the management of absence administration and to provide parents with trustworthy information on absences and presences, as well as come to terms with absenteeism; when confronted with the content of the messages, students are expected to take steps to avoid being late or absent. This reflects a belief in digital technologies as able to make social processes and relations both more knowable and controllable (Selwyn 2015). The text messages can thus be described as part of an ontology wherein they are expected to transform and 'do' something with the absences. In that sense, they become material resources, to be used by humans to achieve certain outcomes.

My point of departure in this paper is akin to this notion of the text messages as 'doing' something. I also believe that the text messages 'do' things with school absences and to educational practices - both inside and outside schools. However, my attention is directed to the practices that exceed what is taken for granted about the messages and their effects, and this is why we began this exploration in my office. In order to fulfil the aim of this paper to study how school absenteeism is produced in a complex entanglement of multiple human and nonhuman material agents I ask myself: What becomes of school absenteeism when text messages are the way parents get to know of a late arrival or an unexcused absence? What affects and practices emerge as effects of these text messages? My interest in digital registration does not seem to be the only reason my colleague Sarah approached me. She is annoyed and irritated but also worried. 'The message affects me physically,' she explains. In this paper, therefore, the investigation of and engagement with text messages shifts slightly: from a story in which the effects of the sending and receiving of text messages are inscribed with a predetermined linear logic of cause and effect (that is, the text messages reduce school 
absenteeism), to a story in which the effects are not predetermined but are inevitably entangled with affects that produce both emotions and educational practices.

In the upcoming section, the theoretical and methodological approach of going with the affective flows of digital text messages will be presented. An analysis will follow of the way the materiality of these text messages is simultaneously affectively productive and affectively produced. The article concludes with a discussion of how the knowledge produced in the affective flows of the text messages itself produces new stories of school absenteeism.

\section{Going with the affective flows of text messages - a theoretical and methodological approach}

By presenting some of the most recent research in the field of affect theory/methodology in the social sciences, which has been referred to in terms of a turn to affect, or the affective turn (Clough and Halley 2007; Hemmings 2005), this section will introduce the theoretical and methodological approach that makes it possible for me to 'go with the affective flows' of text messages. Within the affective turn, affect has been theorized as the pre-personal or preindividual bodily capacity to affect and be affected, or the expansion or reduction of a body's capacity to act (Clough and Halley 2007). This characterization of affect follows Brain Massumi in his notes on the translation of $A$ Thousand Plateaus, by Gilles Deleuze and Felix Guattari (1987, xvi), and builds on the theorizations of affect by Spinoza. What is central to this theorization is that affect is not reducible to the perceptions of individual subjects, nor to emotions. According to MacLure (2010, 284), affect in a Deleuzio-Guattarian sense is not feelings or emotions, but emerges on and through the body as 'facial expressions, tone of voice, breath and sounds'. While affects are never reducible to emotions, they are still connected to them since emotions can be theorized as a product of affect (Zembylas 2007, 26, with reference to Massumi [1996]).

Research focussing on the production of affect, although often connected to critical psychology (see for example, Wetherell 2012; Blackman 2007; Juelskjær, Staunæs and Ratner 2013), departs from various strands of thoughts. Wetherell $(2012,4)$ emphasizes that her interest is not on nonhuman affects, whereas Juelskjær, Staunæs and Ratner $(2013,1136)$ underline that affect is always more than human. In this paper, I will put to work a theorization of affect as a force to explore 'the emotive and somatic, material and non-material "forces of encounter" as bodies, human and nonhuman, meet and depart company' (Roelvink and Zolkos 2015, 47). This is 
inspired by a posthumanist strand of thought that 'does not privilege human interpretation or conscious perception' (MacLure 2011, 999) and in which therefore 'the bodies that are animated by affect are by no means restricted to human bodies’ (ibid). Accordingly, affect is entangled with both discourse and matter, both the human and the nonhuman, and both content and form (Staunæs and Pors 2015, 101). These entanglements can be theorized as affective assemblages (Kofoed and Ringrose 2010; Mulcahy 2012; see also Severinsson, Nord and Reimers 2015). The Deleuzian concept of the assemblage, as a 'contextual arrangement in which heterogeneous times, spaces, bodies and modes of operation are connected' (HickeyMoody 2013, 94) decentres the location of affect. The concept enables a theorizing of how affect belongs neither to a specific body, nor a specific technological tool, nor a specific place/space, but emerges in entanglements of the assemblage (Mulcahy 2012, 12). In line with this, within the paper I refer to the components that constitute an assemblage as 'multiple agents' to emphasize that “"assemblages” can be made up of all manner of matter: corporeal, technological, mechanical, virtual, discursive and imaginary, that carry affective charges' as expressed by Renold and Ivinson (2014, 364).

A theorizing of affective assemblages needs to account not only for the 'non-anthropomorphic organic others, but also for those technologically mediated, newly patented creatures we are sharing our planet with’ (Braidotti 2013, 103). Text messages could hardly be described as 'newly patented creatures'. But when it comes to the educational relations between families and schools, the connections between the digital registration of absences and presences in software like Dexter and the automated text messages connected to the software could be described as a new feature. When Castelli and Pieri (2007) investigated the attitudes to mobile-mediated home-school relations, mobile phones were described by students, parents and teachers as effective, quick and necessary tools for communication (see also Grant 2009). Nevertheless, these authors describe a future in which text messages might come to have 'an almost Orwellian character, where the parent is informed of the eventual absences, delays and grades of the child in real time via SMS, in order to be able to be always informed about the child at all times' (Castelli and Pieri 2007, 183).

What ten years ago was thought of as a threat yet to manifest - an Orwellian future - is now present in most public schools in Sweden (Bodén 2016a). But as Sarah's reaction in our office shows, the text messages can still be received as a threat that hits - simultaneously - the eye and the guts. The text message arriving on her smartphone, sparks embodied affects as she 
rushes to my desk, holding her phone in trembling hands and stating that the message affects her physically. It could be claimed that both text messages and affects flow. Text messages are embedded in conceptions of a sender (the school) and a receiver (the parent) and are expected to travel with trustworthy information concerning school absenteeism. The flows of the messages can thus be theorized as trapped within a linear logic - a from and a to - in which they are expected to obtain certain goals in the hands of human control. In contrast to this, flows of affect have been described as promiscuous and shifting (Kofoed and Ringrose 2012, 9). Affect theorized as a force that produces or encumbers a body's capacities to act entails that these capacities will in turn produce further single or multiple affects, which results in an always on-going movement (Mulcahy 2012). However, and as will become apparent as the text messages are engaged with more closely, this could also be said of the text messages. Even if the messages usually flow from one point to another, they are never on a one-way journey. In affective assemblages of humans and nonhumans, the text messages can no longer be theorized as neutral resources with predetermined effects. Rather, they make way for both expected and unexpected things to happen in relation to school absenteeism. 'They stir things up,' as Sarah describes it. The text messages thus seem to be powerful materialities not only in the sense that they are expected to lower absence rates, but also in the sense that they produce practices, emotions and bodily reactions. In that sense, the linearity of the text messages needs to be related to how various affects also hinder and multiply the predetermined effects of the text messages. The text messages both flow with and against notions of linearity, entailing an affectivity that results in various practices and movements. This affectivity can be theorized as a 'capacity of influencing on and through somebody/something' (Staunæs and Pors 2015, 102), and becomes an example of how 'bodies and parts of bodies interact with nonhuman technology [like text messages] forming ‘affective assemblages' of various scales and intensities' (Kofoed and Ringrose 2012, 10).

The posthumanist view on technology and education running through this paper enables a theorizing of 'the human neither as dominating technology nor as being dominated by it' (Bayne 2015, 15). Rather, humans and nonhumans in their entanglements produce specific practices, emotions and affects. As described by Staunæs and Pors $(2015,102)$ 'the effects of affects can be in the form of human bodily expressions such as blushing, increased heartbeat, chills and shivers, sweaty palms, clammy mouth, nervous twitches.' Within the complex and temporary assemblage Sarah is part of in our office - that I as well inevitably become engaged in - these bodily affects seem to become productive of emotions such as anger and fear. But also of 
material practices, which force her to again grab her phone, and call her son. This conversation in turn sparks annoyance, shown in her raised voice, with her son (as well as with the teacher who did the registration 'just because'), which in turn forces her to phone her partner, which leads to further affects and further phone calls, further text messages, further emotions, further affects, and so on. The text messages could thus be described as engaged in affective flows as they stir things up, become 'stirrers', and productive of both emotions and material practices related to school absenteeism. And how this is enacted and what will be produced is always connected to the various entanglements within the assemblage (Bodén 2013).

Within this paper, 'going with' the affective flows of the text messages is not only a theoretical approach but also a methodological endeavour. The affective flows emerge in entanglements of humans and text messages, discourses and matter. This means that a close and attentive interest must be directed to these flows, to be able to grasp affect 'as flowing activity, as a pattern in which affects are composed, figured, entangled, mobilized, and recruited' (Brøgger and Staunæs 2016, 228, with reference to Wetherell 2012; see also Staunæs and Pors 2015). In line with posthumanist educational researchers theorizing of affect, a methodology of 'going with' forces the researcher to closely follow the affective flows of the text messages in all their twist and turns. This means that a reading of the text messages through theories of affect will throw the researcher backward and forward into new relations (Renold and Ivinson 2014). It could thus be claimed that this methodological approach allows the empirical engagements to 'kick back' (Brøgger and Staunæs 2016, 229) and affect how the research is performed. Accordingly, a 'going with' can be described as an investigation of the affective intensities in the entanglements of theories, methodologies and empirical engagements (Kofoed and Ringrose 2012). It opens up a story in which the affective flows of text messages can be seen as producing - as well as being already entangled with - school absenteeism.

\section{Affective assemblages of school absenteeism}

In this section I engage more intensely with the text messages and with parents, teachers and students at the Björnäng school and Sandö school. With the aim of producing knowledge on practices related to school absenteeism I, in 2012 and 2013, participate in daily events at the two schools - in cafeterias, canteens, classrooms, gymnasiums, hallways, teachers' offices, on buses, in school yards, etc. - as well as at parent-teacher meetings and information meetings at the Educational Office and the IT Unit of the municipality (around 110 hours in total). In 
addition to this I performed interviews and intraviews ${ }^{3}$ with nine teachers and school staff at the two schools, four group interviews with a total of 18 students in Grade 9 from Sandö School, group interviews with four parents from Sandö School and an interview with a mother of a student at Björnäng School. This means that the three examples discussed in the following analysis emerge from what I understood as an extensive assemblage of school absenteeism that involves a multiplicity of human and nonhuman agents both inside schools (computer software, smartphone applications, schedules, students, teachers, etc.) and outside schools (e-mails, parents, smartphones, telephone calls, students, etc.). As will become clear in these three examples, a methodology of 'going with' the flows both includes more and other human and nonhuman bodies than outlined here and blurs the boundaries between the examples, between homes and schools, and between senders and receivers.

\section{From close, to a distance?}

The software Dexter has become a well-known co-producer of information about school absences at both schools. The word 'Dexter' has transformed from being solely the name of the software to being part of the everyday language related to school absences and presences. Teachers invented the word 'Dextra' to describe practices of making an absence registration and students refer to being late or absent as getting 'a Dexter' or being 'Dextered'. In an interview, Titti, the mother of Evelina in Grade 7 at Björnäng School, describes how getting 'a Dexter' has become a synonym for getting information about her daughter's late arrivals or unexcused absences. Rather than thinking of 'a Dexter' in terms of a linguistic or discursive representation of late arrivals or unexcused absences, 'a Dexter' can be theorized as a an example of how discourses are entangled with both the materiality of the text messages and the affects produced in these relations. Compared to previous ways of working with school absence registration - when the registration was done together with nonhuman agents as notebooks or paper sheets - the digital registration and the text messages expand and accelerate the phenomenon. In a blink of an eye, i.e. in a click on the computer mouse, 'a Dexter' entangles students, parents and the school. 'A Dexter' becomes both the action (that is having an unexcused absence registered) and the sanction (that is getting a text message). How 'a Dexter' is closely connected to discourse on school absenteeism, to affects and to the materiality of the

\footnotetext{
3 Rather than being a conversation about the computer and Dexter, the intraviews were performed together with the computer when the teachers performed the Dexter registrations. In the intraviews, my interest was directed to how entanglements of the participating teachers and Dexter was enacted I these conversations, and how knowledge on school absenteeism was produced when Dexter was regarded as an equally important 'speaker'. The intraviews can thus be described as a methodology that include nonhuman 'voices', and questions the humancentrism of conventional qualitative interviewing (cf. Bodén 2015; 2016a).
} 
text messages is shown in the following, where, during a group interview with parents from Sandö School, Kerstin, the mother of Disa in Grade 9, describes her reaction when she first got a text message.

\begin{abstract}
The first time I got 'a Dexter' I got really nervous. 'God, what do I do now then! Oh, my daughter is late!' So I phoned the school: 'Yes, hello, this is Kerstin, Disa's mom, I just received a messages that she has arrived late. What should I do now? I've got it on my phone, you know,' I explained. The teacher answered: 'That's not a problem, just take it easy, it's just information for you that she, that she was late today, and you don't have to do anything.'
\end{abstract}

Notions of what the text message might imply outside of what the message actually states seem to cause an instant nervousness: Is Disa ok? Is she playing truant? Has something happened to her on her way to school? On Kerstin's smartphone, the reception of a message is at the same time audible (a new text message immediately causes a sound from the phone), sensory (the phone begins to vibrate), and visible (the home screen instantly displays the message). The 'stirring' disturbance of the materiality of the text message - created by the sound, the visuals and the vibration - hits as an immediate bodily sensation before the content of the message is taken note of. It could thus be claimed that the text message and the smartphone as nonhuman material agents becomes entangled with, and even reinforces, the discourses and notions on what a message might imply: a truanting daughter. The nervousness Kerstin describes in the interview could be theorized as connected to an intense and affective sensation of guilt as her daughter got 'Dextered'. Accordingly, it becomes necessary to phone the school to confirm that Disa is ok, but also to show that she cares about the schooling of her daughter. But when Kerstin phones the school, nothing happens. So she asks me and the three other parents in the group interview:
But then I wonder, is that the way it should be, a one-way communication? The school must tell me that my daughter was late, 'keep an eye on her,' this is just to tell you that she has been late? Eh, I do not know, would they like to have a re-confirmation, do you understand? [...] What is the idea of sending it to me then? Is it because I should know that my daughter was late? But 'We [the school] don't, we don't care about whether you know it or not.' Do you understand how I'm thinking? 'You can do what you want about it, we have just keyed it in [registered it], it is our duty to do it because we have this system that tells us that we need to inform you as a parent.'

Kerstin speaks faster and faster. The sounds, the visuals and the vibrations the text message evokes on the phone makes it material in a very palpable way. The affective flows of sensations, movements and forces that emerge in the entanglements of the materiality of the text messages, the discourses connected to both schooling and school absenteeism, and Kerstin as a worried 
and engaged parent, seem to change direction when they encounter the placidity of the teacher at the school, who says 'just take it easy.' The nervousness flowing through Kerstin's body is turned instead into feelings of uncertainty on how to handle the information. For each question Kerstin asks me and the other parents in the group interview, the more annoyed she seems to become. Thus, the affective assemblage changes and takes new forms in the entanglements of parents gathered in the room, Kerstin's fast speech, the smartphones relocated from the pockets of the parents to the centre of the table we are sitting around, and myself as a researcher who might be thought of as someone who could actually have a reasonable answer to Kerstin's questions. This makes it apparent that what is produced is not affects as something someone 'has' or 'is' but needs to be understood 'as a tension, a charging, which expresses itself relationally’ (Juelskjær, Staunæs and Ratner 2013, 1136). However, what becomes especially intriguing, is that the affective flows that are produced with the text messages are hindered, stopped, and turned into ‘a one-way communication', as Kerstin expresses it. The emotions and practices can be theorized within the tensions of - on one hand - the insistence on a close collaboration between parents and schools to reduce school absenteeism and the disadvantages of an uninvolved parent (Reid 2015), and - on the other hand - the fast and frequent contact through the text messages. Because, the efficiency in the management of students absences the text messages offer seems to produce distance rather than closeness in the relations between parents and the school. For Kerstin it becomes fruitless to try to collaborate and be an engaged parent. The responsibility of parents remains undefined and vague and 'dislocated' (see Knutsen and Åkerstrøm Andersen 2014), since there is no way to get involved with the messages - they just hit you. The invitation to 'contact the home room teacher if you have any questions' is turned into a 'don't do anything.' Thus, it seems as if the closeness is replaced by a school merely fulfilling a duty by keying in a registration - by 'Dextering' both Disa and her mother.

Receiving a text message makes what is not visible - an absence - visible, and audible, and sensory. There is a sense of getting flooded - with sensations and forces - by the unfathomable that in turn produces both nervousness and guilt. In her description, Kerstin is especially focused on the first time she and her daughter got 'Dextered'. When it comes to the production within the affective assemblage, it seems as if the charm (or rather the shock) of novelty should not be underestimated. In the group interview, Erik (father of Arvid), turns to Kerstin and says: 'But then, unfortunately, mine [his son Arvid] has been a little less well-behaved than yours [Kerstin's daughter Disa], a few times. So I've gotten quite used to it'. If the text messages become too many, their capacity as stirrers seems to be reduced. Rather than guilt or 
nervousness, indifference emerges. However, the number of 'Dexters' and the fact that they are always near at hand could also produce emotions of being in control of the absenteeism: 'Pick up the phone, and you can handle the problem at once. That's what I like about Dexter' as Olle (father of Rolf) describes it in the group interview. For some parents the visibility of absences the text messages offer seem to also convey a sense of comfort, calmness and control, as the messages become something to look at, read and to return to, to hold and to hold on to. The text messages make absences graspable in a very literal sense; you can put the absences and late arrivals in your pocket then pick up the phone later and show it to your child when he or she gets home. More absences give more messages, give a more trustworthy and 'heavier' phone. Within this assemblage, the repetition of the messages - especially on smartphones where all messages from the same sender are in the same thread - could almost be thought of as producing a practice where 'the more messages, the merrier'. Whereas at the same time, 'a Dexter' is what you really want to avoid.

\section{From Sweden, to Dubai?}

'Going with' the affective flows will now take us to a distant place (at least in relation to the Swedish municipality where this study took place): Dubai. But we will begin at an information meeting about Dexter in the IT-unit of the municipality. At the meeting the participating teachers, principals and the IT-managers of several schools of the municipality, as well as myself, learned that all holiday trips would be regarded as unexcused absences if the principal of the school had not approved a holiday application. Accordingly, all students who go on holidays when school is in session would be registered as absent without permission, and text messages would be sent. This is something the teachers at Sandö School have taken note of, as shown in the following discussion in the teachers' office.

\begin{tabular}{|c|c|}
\hline Anna & $\begin{array}{l}\text { Sebastian is on vacation now, without getting it granted from the } \\
\text { principal. So we have to report him as absent. Although the other } \\
\text { students in his class will say he's on a vacation, we need to report it } \\
\text { as unexcused absence. }\end{array}$ \\
\hline Sanna & Where is he now? \\
\hline Anna & $\begin{array}{l}\text { Dubai or something, maybe. But we have disconnected the text } \\
\text { message service, so they don't get messages every day. You don't } \\
\text { have to rub salt in the wounds, you know. }\end{array}$ \\
\hline gneta & It would surely be funny if they got the text messages in Dubai. \\
\hline
\end{tabular}

There is a cheerful atmosphere in the office, and Agneta cannot hold back her laughter when she mentions sending text messages to Dubai (Might they reach the family on the back of a 
camel on a desert trip? Travel all the way up to Burj Kalifa? Or into the indoor ski resort?). The reporting - the 'Dextering' - is done, but the disconnection of the automated messages is in opposition to what was said at the IT-unit meeting. In this example, the affective flows of the text messages, and the emotions and practices the text messages might produce, seem to be inevitably part of teachers' processes of 'Dextering'. Who would want to stir someone up on a camel back, or on top of the world's tallest building?

With other flows and connections, other practices are produced. This is shown in the following, when Agneta sits down at the computer to do the registration, in the teachers' office. In my memory notes from the Sandö School I have written:

'The parents will be annoyed with us now' Agneta says, facing the computer. 'I saw that some of the other teachers have reported him [a student] as missing, so his parents will get a text message.' Agneta explains (and adds that she knows she is whining) that it is important that the parents behave the way they should, since the school has carefully told them what to do when their children need to be away from school. I ask if the text message becomes a way to remind the parents to remember to phone the answering machine. 'Exactly, they should do that,' Agneta answers.

Within this example, the affective flows of the text messages as stirrers is not something Agneta wants to avoid, but rather to engage with to remind parents of their responsibility to report their child's absence, just as the school has 'carefully told them.' However, as stirrers, the text messages do not only become resources to show parents the school's displeasure or disappointment; they produce nervousness and anxious among teachers as well. My memory notes from the teachers' office continue:

\footnotetext{
Agneta proceeds with the registration. The moment after she has stated that parents have to behave, she bursts out: 'Didn't I get a holiday application?' With fumbling, paper-seeking hands she starts to look through her papers on the desk. 'Yes, yes, there it is! Oh, I’m lucky!'
}

The intense sensation when realising she might be about to make a registration mistake lasts only for a second and when the application is found Agneta turns to the computer again. She is lucky, lucky that she did not make an incorrect registration when she should have known better. The flows produced within this affective assemblage - from being in full control and able to annoy parents, to being tremendously nervous, to being totally relieved and lucky - are over in a flash. But Agneta discusses this fear further with her colleague Leif in one of our interviews: 
Leif Yes, but if you are a bit stressed and you're on your way to something, we have had excursions and stuff, and then you have to, to do the registration in the morning, it could even happen that you click on the wrong kid then. Because it has to be so quick.

Agneta But that makes it...I'm afraid that this would happen as they get text messages. It cannot happen, Leif.

The stress makes the 'Dextering' a very intense encounter. 'It cannot happen, Leif'; a mistake cannot be made because that will inevitably produce a number of emotions as the affective flows of a text message reach the wrong parent, whose reaction could be who knows what. At other times, the stress makes it impossible to even have time to 'Dextra'. 'If I have lesson after lesson like this and also should have time to go in and fill in the absences or presence and so...I think that can be a bit stressful' says the teacher Maria from Sandö School. She tells me how she, the previous day, had not had the time to 'Dextra' before she got home, at half past five. When sitting at home at the kitchen table together with her children, Maria had suddenly remembered. 'That's not good,' she explains, 'because that means that the parent won't get the message until the evening, saying that the child was late in the morning.' The moment at the kitchen table, realizing she had forgotten something important, even though she had been literally unable to do anything about it at the time, seemed to produce an intense encounter.

In such ways, with the affective flows of text messages, school absenteeism flows not only to the homes of students but also to the homes of teachers. The possibilities the technology offer in terms of being accessible also from the home of the teachers can be described as reshaping the processes around the registration. And at the same time, the technological potentials of ' $\mathrm{a}$ Dexter' can be claimed to reinforce discourses on the importance of a speedy contact with the parents of absent students. Maria returned to the anecdote several times during my time at the school and she even told me that she 'would be a bit special for you as a researcher to follow as I sometimes forget to do the registration.' What is striking is that Maria was one of a few teachers at Sandö School who had a Dexter-application on her smartphone to ease the task of registration in the classroom. The reason Maria had been granted this application was that the statistics of completed registrations had shown that she registered more than $95 \%$ of her lessons. In this case, the affective flows of the registration seem to be more reliable than statistical measures. The 'do's and don'ts' of the registration are very present. In an interview, the teacher Malin from Björnäng School summarizes this: ‘No, you can’t wait a whole day before doing it. You are not allowed to, that would cause an error.' The Education Act (SFS 2010:800, 7 kap. $17 \S)$, that states that parents need to be informed on the same day about an absence, has 
undoubtedly become an entangled part of the affective assemblage too. 'I know of a parent who contacted the school and didn't think it was that much fun to receive a message at half past eleven in the evening,' said the teacher Anna from Sandö School, laughing.

Affective flows of text messages to Dubai could be thought of as an exception, but an exception that highlights the ordinary. Myriads of flows produce a variety of emotions and practices: intense sensations of being afraid to send an incorrect message or of forgetting a holiday application, the relief when one does not slip up, and the somewhat thrilling feeling (perhaps of power) that text messages could be engaged with to evoke a parallel anxiety or annoyance in a parent who does not behave. This becomes crucial in relation to school absenteeism. Because the sending - or not sending - of a text message is not an isolated practice, but is always connected to the registration, in the software Dexter, of unexcused absences and late arrivals. As Anna (teacher, Sandö School) states: 'We have decided on not registering a late arrival if it is less than five minutes, because of the messages sent to parents.' Thus, it could be claimed that rather than being problem-solving tools to reduce school absenteeism, sent from the school to the parent, the affective flows of the text messages are already part of what is registered or not. The fast and frequent parental contact might thus produce practices where messages are not sent. Accordingly, text messages do not become solely information on a student's absenteeism, but inevitably part of how school absenteeism is produced, enacted and handled.

\section{From schools, to parents, to students, to schools?}

It can be said that the flows of text messages entangle the absences and presences of students not only with the teachers and the school, but also with their parents. However, what seems common among the diverse affective flows that have been engaged with so far in the paper, is that these flows rarely touch upon those that should be most inextricably interwoven with the text messages: the students. This final part of the analysis will focus on the affective entanglements of the students and the text messages.

In a group interview, students in Grade 9 at Sandö School described the text messages as the primary way in which they get information about their own late arrivals or unexcused absences, but not directly from the text messages - since they are only sent to parents' phones - but via their parents. Several of the students describe how their parents text them as soon as they get 'a Dexter'. Disa relates that sometimes when she gets home her mother tells her 'You were late 
today,' and that it is not until then that she learns that a registration has been made and a text message been sent: 'And then you don’t even know what lesson it was unless your parents tell you.' Alice explains how this produces - what could be theorized as - an ongoing flow that changes direction multiple times when a registration mistake is made. Sometimes when she has participated in the school choir or in various sport events (activities that should be registered as excused absences, which means that no text message should be sent), a text message is still sent to her parents. This means that her mother confronts her, straight away. 'And then I ask the teacher, you know. And explain what I did.' Usually the teacher then changes the registration from unexcused to excused absence. Thus, when entangled with students, the affective flows of the text messages seem to fly freely but far from straightforwardly - from the school, to the parent, usually to the student, and back to the school.

I was really puzzled by the reaction of students. Among parents and teachers, annoyance, anxiety, nervousness and anger produce a variety of bodily movements and material practices; yet, in the students' entanglements with the text messages, it is indifference, insouciance and even boredom that seem to recur. In a group interview I asked four of the students how their parents approached them if they had 'a Dexter'.

\begin{tabular}{|c|c|}
\hline Linnea & $\begin{array}{l}\text { How do they get in touch then... send you a text message? If a } \\
\text { Dexter text message arrives, do your parents send... }\end{array}$ \\
\hline Gunvor & $\begin{array}{l}\text { Yes, like this... Not only, but you know... and ask why I was late. } \\
\text { How... Do they do that to you as well or...? }\end{array}$ \\
\hline Rolf & $\begin{array}{l}\text { Yes, or they take it when I get home. And they ask an enormous } \\
\text { inquiry [sic] about why I was late. }\end{array}$ \\
\hline Dlof & Yeah... And then you tell the reason and it's over, right. \\
\hline
\end{tabular}

Flows of affect seem almost absent. 'At first I think many [of us] cared, because there was a lot of gabble about it, like 'Oh no, the teacher registered it in Dexter,' but now I don't think that anyone cares,' as Rolf describes it. As the students were those who in the end would be most affected - or troubled - by the text messages, my expectation was that they would also be those engaged in the most intense affects. However, the statement by another student, Madde, that ' $I$ never think about Dexter' makes it apparent that the affective assemblages need to be engaged with closely, in their intricate web of materialities, discourses and emotions. When parents get a message, sent from Dexter, the ability to react to it is limited (Who to respond to? The software, the teacher, the school? Who is the sender?) which seem to become productive of both nervousness and annoyance. Knowing that the text message is sent from 'no one' (let's for 
a moment presume that the software Dexter is 'no one'), to 'any one' (Dexter does not care whether the intended parent gets the message, or about the reactions of the receiver) seems to make it more annoying. 'What is the idea of sending it to me then?' Kerstin asks. When teachers do a registration, affective flows connected to the receiving parent seem to be an entangled part of the assemblage. But when students see, hear and feel a text message on their phones (or get the information when they get home), it is not 'a Dexter', but a text message sent from their parents. The students could be described as the ones furthest from the affective flows of the text messages; the text messages flow through both the school and the parents before they hit the students. If they do. And if they do, they seem fairly easy to steer in another direction, as the student usually has the chance to clarify what happened. As Olof declares, 'Yeah... And then you tell the reason and it's over, right,'

The possibility of handling the text messages does not seem to be the only reason the students are indifferent to them. Indifference and boredom with the text messages could also be theorized as produced together with their repetitive nature; they are sent everyday and almost everyone gets them - whether they have a 'problem' with absenteeism or not. The stirring potential of the text messages is thus watered down and seems almost absent. As theorized by Anderson (2004, 751) such

[b]oredom takes place when a whole series of bits and pieces are 'held together'
under a type of relation that discloses a situation of reiterative 'bare' repetition.
By thereafter attuning to the colour of boredom, its greyness, it becomes a
malady of a body's capacity to affect and be affected.

The repetitive nature of the text messages thus reduces their capacity to affect and be affected. What is interesting is however that the students' capacities to act do not seem to be reduced. Rather, when information about an incorrect text message reaches the students (as in the case of Alice), they seem to (re)act immediately. Even though students are used to getting the messages, an incorrect message is entangled with other emotions, materialities and practices and thus appears as something new and bright, rather than dull and grey. And even though parents 'ask an enormous inquiry', the flows appear to be ongoing and connected to new possibilities within the affective assemblage and seem to broaden for the student the possibility of becoming a strong actor, one that can question both the text messages and the registrations. So, what was common among the students was not that they wanted fewer text messages, but more of them. Or rather, they wanted them to flow directly to their own phones - they wanted 'a Dexter' - where the affective flows of the assemblage would stay rather than hit and leave. 
Rolf (student in Grade 9, Sandö School) points to something interesting when wishing he could get the messages himself:

When you see them, you know, when you get the text message, a conversation [on the smartphone] is created, then in the end you'll see that, you know, oh this is getting a bit too much. Then it's easier to pull yourself together.

As pointed out by for example Richardson (2014), teenagers are well aware of how powerful smartphones are. Both when it comes to being controlled, and being able to control different practices. In relation to Rolf's statement it seems as if the students want the text messages to stir things up. Or rather, they want to engage in entanglements with the materiality of a screen filled with 'Dexters' - both repetitive and many - that will hit in the guts, produce a bodily sensation that opens up possibilities for the production of emotions like worry or insight, that in turn will become part of an ongoing flow that will help students pull themselves together.

\section{Conclusions: what do the affective flows produce in relation to school absenteeism?}

The theoretical and methodological approach of 'going with' the affective flows of text messages has taken us through three empirical engagements that expand school absenteeism to include the homes of students as well as the homes of teachers, guilt as well as control, 'Dexters' from the school as well as (boring?) text messages from parents, and stirrers. These engagements have produced knowledge on the flows as part of a complex affective assemblage that - depending on the entanglements within the assemblage - can work in both affirmative and destructive ways, and thus become productive of various forms of emotions and different practices connected to school absenteeism. Depending on the context, what the different bodies - both human and nonhuman - that are part of the assemblage will produce can never be known in advance, but is always a product of the particularities and temporalities of their entanglements. Within the assemblages, the bodily affective sensations in an encounter with 'a Dexter' can produce emotions like nervousness and guilt and thus produce a practice of immediately phoning the school to get information about what has happened. In entanglements with discourses on how to reduce school absenteeism, this phone call can simultaneously be theorized as part of producing the engaged and caring parent, who values close contact with the school. And when hindered, annoyance emerges. However, the encountering of 'a Dexter' can produce feelings of being in control, which in turn can also produce emotions and practices related to care, this time by showing the text messages to your child and thus 'handling the problem at once.' An intense encounter with a holiday application may produce emotions like 
joy and relief that in turn will produce a practice where registration and the sending of a text message is avoided. The equally intense feeling of having the power to annoy a parent who has forgotten to report a sick student might produce a practice where the sending of a text message becomes especially important. And the assemblage can produce indifference and boredom, and practices of wanting to say: 'Boredom, boredom, go away, I want my 'Dexters' myself'.

The knowledge produced here on the affective flows of text messages shows that the anticipated or desired effects of the text messages - to reduce school absenteeism - are not their only effects. Theorizing text messages as entangled with flows of affect shows that the even if the text messages are usually flowing from one point (the school) to another (the parents) in a linear fashion, the predetermine logic of cause and affect (i.e., the text messages will reduce school absenteeism) often associated with the messages is far from linear. 'Going with' the flows highlights how the effects of the text messages are also effects of affects. This means that the text messages not only affect ('affect' used here as a synonym for influence) school absenteeism after they reach the parent and the student. Just as questions about Dubai or misbehaving parents become part of how the registrations are performed and which text messages are sent, the ongoing affective flows and the productions within the assemblage form and reform school absenteeism before the text messages flow. As holiday applications are found during the registration or teachers remember at their dinner table at home what stress has made them forget, the affective flows form and reform school absenteeism simultaneously as the text messages flow. As students become indifferent to the text messages, school absenteeism is formed and reformed after the text messages are sent but not at all in the predetermined way. And, as parents receive a text message at half past eleven in the evening, school absenteeism is formed and reformed in the future, rather than at the time the student arrived late or was absent. The affective flows of text messages thus travel in all directions, with and against notions of linearity. Undoubtedly, this produces new stories on school absenteeism and queers spaces, places and times (see also Bodén 2016b), which take us back to where we started, to my office and my colleague. What happened to the text messages on her phone, to her annoyance and anxiety? Sarah ended up unsubscribing to the messages and forcing her partner to receive them instead. This created a temporary peace, at least for Sarah. But, you cannot renounce them completely; someone in the family has to have their number registered in the software. Someone, anyone... but not the student. 


\section{References}

Anderson, B. 2004. “Time-stilled Space-slowed: How Boredom Matters.” Geoforum 35: 739_ 754. doi:10.1016/j.geoforum.2004.02.005.

Attwood, G., and P. Croll. 2006. "Truancy in Secondary School Pupils: Prevalence, Trajectories and Pupil Perspectives.” Research Papers in Education 21 (4): 467-484. doi: 10.1080/02671520600942446.

Bayne, S. 2015. “What's the Matter with 'Technology-enhanced Learning’?” Learning, Media and Technology 40 (1): 5-20. doi: 10.1080/17439884.2014.915851

Blackman, L. 2007. "Feeling F.I.N.E: Social Psychology, Suggestion and the Problem of Social Influence.” International Journal of Critical Psychology 21: 23-49.

Bodén, L. 2013. “'Seeing Red?’ The Agency of Computer Software in the Production and Management of Students' School Absences.” International Journal of Qualitative Studies in Education 26 (9): 1117-1131. doi: 10.1080/09518398.2013.816887.

Bodén, L. 2015. "The Presence of School Absenteeism: Exploring Methodologies for Researching the Material-Discursive Practice of School Absence Registration”. Cultural Studies $\Leftrightarrow$ Critical Methodologies 15 (3): 192-202. doi: 10.1177/1532708614557325.

Bodén, L. 2016a. "Present absences: Exploring the posthumanist entanglements of school absenteeism.” PhD diss., Linköping University.

Bodén, L. 2016b. "Dexter Time: The Space, Time, and Matterings of School Absence Registration.” Discourse. Studies in the Cultural Politics of Education 37 (2): 245-255. doi: 10.1080/01596306.2015.1010073.

Braidotti, R. 2013. The Posthuman. Cambridge/Malden: Polity Press.

Brøgger, K., \& Staunæs, D. 2016. "Standards and (Self)Implosion: How the Circulation of Affects Accelerates the Spread of Standards and Intensifies the Embodiment of Colliding, Temporal Ontologies.” Theory \& Psychology 26 (2): 223-242. doi: 10.1177/0959354316635889.

Bhalla, V., T. Singla, A. Gahlot and V. Gupta. 2013. "Bluetooth Based Attendance Management System.” International Journal of Innovations in Engineering and Technology 3 (1): 227-233.

Carroll, H.C.M. 1986. "Parental Factors in Primary School Pupil Absenteeism and Their Possible Implications for Educational Psychologists.” Educational and Child Psychology 3 (3): 202-212.

Carroll, H.C.M. 2015. "Pupil Absenteeism and the Educational Psychologist.” Educational Studies 41 (1-2): 47-61. doi:10.1080/03055698.2014.955731.

Castelli, S. and M. Pieri. 2007. "Mobile-mediated Home-school Partnership: Attitudes and Expectations of Teachers, Parents and Students.” International Journal about Parents in Education 1 (0): 182-187. 
Clough, P.T. and Halley, J.O., eds. 2007. The Affective turn: Theorizing the Social. Durham: Duke University Press.

Deleuze, G., and Guattari, F. (1987). A Thousand Plateaus. Minneapolis, MN: University of Minnesota Press.

Ervasti, M., M. Isomursu and M. Kinnula. 2009. "Bringing Technology into School - NFCenabled School Attendance Supervision.” Paper presented at the 8th International Conference on Mobile and Ubiquitous Multimedia (MUM09), Cambridge, UK, November 22-25.

Gavade, S., P. Atwal, Z. Khan, V.R. Pillai and B. Chandargi. 2015. “Automated Bluetooth Attendance Management System.” International Journal of Computer Science Engineering and Information Technology Research 5 (2): 7-14.

Grant, L. (2009). Children's Role in Home-School Relationships and the Role of Digital Technologies. Bristol, UK: Futurelab.

Gunnarsson, K. 2015. “Med önskan om kontroll: Figurationer av hälsa i skolors hälsofrämjande arbete.” PhD diss., Stockholm University.

Helmersson, E. 2014. "Hårdare tag fungerade mot skolket” [Tougher constraints helped prevent truancy]. Dagens Nyheter, November 17. Retrieved from http://www.dn.se/ledare/signerat/hardare-tag-fungerade-mot-skolket/

Hemmings, C. 2005. "Invoking Affects: Cultural Theory and the Ontological Turn”. Cultural Studies 19 (5): 548-567. doi: 10.1080/09502380500365473.

Hickey-Moody, A. 2013. “Affect as Method: Feelings, Aesthetics and Affective Pedagogy.” In Deleuze and Research Methodologies, edited by Rebecca Coleman and Jessica Ringrose, 79-95. Edinburgh: Edinburgh University Press.

Isomursu, M., M. Ervasti, M. Kinnula and P. Isomursu. 2011. "Understanding Human Values in Adopting New Technology - A Case Study and Methodological Discussion.” International Journal of Human-Computer Studies 69: 183-200. doi: 10.1016/j.ijhcs.2010.12.001.

Juelskjær, M., D. Staunæs and H. Ratner. 2013. “The Return of the Freudian Couch ${ }^{\circledR}$ : Managing Affectivity Through Technologies of Comfort.” International Journal of Qualitative Studies In Education 26 (9): 1132-1152. doi: 10.1080/09518398.2013.816885.

Kofoed, J. and J. Ringrose. 2012. "Travelling and Sticky Affects: Exploring Teens and Sexualized Cyberbullying through a Butlerian-Deleuzian-Guattarian Lens.” Discourse: Studies in the Cultural Politics of Education 33 (1): 5-20. doi: 10.1080/01596306.2012.632157. 
Knudsen, H. and N. Åkerstrøm Andersen. 2014. "Playful Hyper Responsibility: Toward a Dislocation of Parents’ Responsibility?” Journal of Education Policy 29 (1): 105-121. doi: 10.1080/02680939.2013.791929.

Lodha, R., S. Gupta, H. Jain and H. Narula. 2015. "Bluetooth Smart Based Attendance Management System.” Procedia Computer Science 45: 524-527. doi: 10.1016/j.procs.2015.03.094.

MacLure, M. 2010. “The Offence of Theory.” Journal of Education Policy 25 (2): 277-286. doi: 10.1080/02680930903462316.

MacLure, M. 2011. “Qualitative Inquiry: Where are the Ruins?” Qualitative Inquiry 17 (10): 997-1005. doi: 10.1177/1077800411423198.

Markström A-M. 2013. “Children’s Perspectives on the Relations between Home and School.” International Journal about Parents in Education 7: 43-56.

Massumi, B. 1996. “The Autonomy of Affect.” In Deleuze: A Critical Reader, edited by Paul Patton, 217-239. Oxford: Blackwell.

More, V. and S. Nayak. 2013. "Attendance Automation using Near Field Communication (NFC) Technology.” International Journal of Scientific \& Engineering Research 4 (12): 572-575.

Mulcahy, D. 2012. “Affective Assemblages: Body Matters in the Pedagogic Practices of Contemporary School Classrooms.” Pedagogy, Culture \& Society 20 (1): 9-27. doi: 10.1080/14681366.2012.649413.

Reid, K. 2015. “Introduction to Special Edition.” Educational Studies 41 (1-2), 4-13. doi: 10.1080/03055698.2014.955724.

Renold, E. and G. Ivinson. 2014. "Horse-Girl Assemblages: Towards a Post-Human Cartography of Girls' Desire in an Ex-Mining Valleys Community.” Discourse: Studies In The Cultural Politics Of Education 35 (3): 361-376. doi: 10.1080/01596306.2014.888841.

Richardson, J.M. 2014. "Powerful devices. How teens' smartphones disrupt power in the theatre, classroom and beyond”. Learning, Media \& Technology 39 (3): 368-385. doi: $10.1080 / 17439884.2013 .867867$

Roelvink, G. and M. Zolkos. 2015. "Affective Ontologies: Post-humanist Perspectives on the Self, Feeling and Intersubjectivity.” Emotion, Space \& Society 14: 47-19. doi: 10.1016/j.emospa.2014.07.003

Sandin, B. 1986. "Hemmet, gatan, fabriken eller skolan: Folkundervisning och barnuppfostran i svenska städer 1600-1850.” PhD diss., Linköping University

Selwyn, N. 2011. “'It’s all about Standardisation': Exploring the Digital (re)configuration of School Management and Administration”. Cambridge Journal Of Education 41(4): 473488. doi:10.1080/0305764X.2011.625003 
Selwyn, N. 2015. "Data Entry: Towards the Critical Study of Digital Data and Education.” Learning, Media and Technology 40 (1): 64-82. doi: 10.1080/17439884.2014.921628

Severinsson, S., C. Nord and E. Reimers. 2015. “Ambiguous Spaces for Troubled Youth: Home, Therapeutic Institution or School?” Pedagogy, Culture \& Society 23 (2): 245264. doi: 10.1080/14681366.2014.977807.

SFS [Swedish statues]. 2010:800. Skollag [Education Act].

Skolverket. 2008. Rätten till utbildning: Om elever som inte går i skolan. Rapport 309. Stockholm: Fritzes

Skolverket. 2010. Skolfrånvaro och vägen tillbaka: Långvarig ogiltig frånvaro i grundskolan. Rapport 341. Stockholm: Fritzes

Sjöberg, M. 1996. ”Att säkra framtidens skördar: Barndom, skola och arbete i agrar miljö: Bolstad pastorat 1860-1930.” PhD diss., Linköping University

Staunæs, D. and J.G. Pors. 2015. ”Thinking Educational Policy and Management Through (Frictional) Concepts of Affects.” In Education Policy and Contemporary Theory: Implications for Research, edited by Kalervo N. Gulson, Matthew Clarke and Eva Bendix Petersen, 99-109. Abingdon: Routledge.

Sundén Jelmini, M. 2014. “Nytt projekt minskar skolk” [New project reduces truancy]. Svenska Dagbladet, November 17. Retrieved from http://www.svd.se/nyheter/inrikes/nytt-projekt-minskar-skolk_4106395.svd

Wetherell, M. 2012. Affect and Emotion: A New Social Science Understanding. London, UK: Sage.

Williamson, B. 2016. Digital Education Governance: An Introduction. European Educational Research Journal 15 (1): 3-13. doi: 10.1177/1474904115616630.

Zembylas, M. 2007. "The Specters of Bodies and Affects in the Classroom: A RhizoEthological Approach.” Pedagogy, Culture \& Society 15 (1): 19-35. doi: 10.1080/14681360601162030. 